
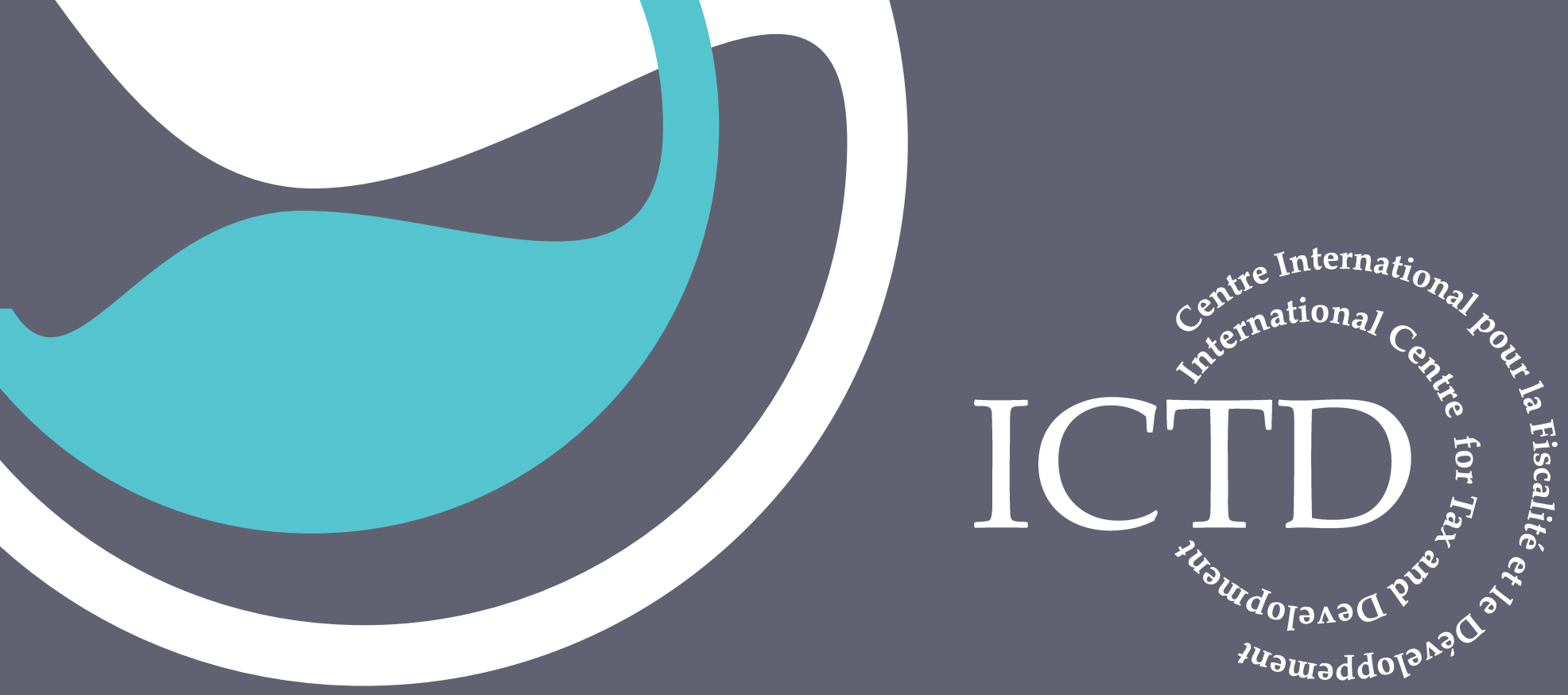

Working Paper 60

\title{
Improving the Performance of Natural Resource Taxation in Developing Countries
}

Michael C. Durst

November 2016 
ICTD Working Paper 60

\section{Improving the Performance of Natural Resource Taxation in Developing Countries}

Michael C. Durst

November 2016 
Improving the Performance of Natural Resource Taxation in Developing Countries

Michael C. Durst

ICTD Working Paper 60

First published by the Institute of Development Studies in November 2016

(C) Institute of Development Studies 2016

ISBN: 978-1-78118-330-4

\section{(c) (1) $\$$}

This is an Open Access paper distributed under the terms of the Creative Commons Attribution Non Commercial 4.0 International license, which permits downloading and sharing provided the original authors and source are credited - but the work is not used for commercial purposes. http://creativecommons.org/licenses/by-nc/4.0/legalcode

\section{Available from:}

The International Centre for Tax and Development at the Institute of Development Studies, Brighton BN1 9RE, UK Tel: +44 (0) 1273606261

Email: info@ictd.ac.uk

Web: www.ictd/en/publications

IDS is a charitable company limited by guarantee and registered in England (No. 87733) 


\title{
Improving the Performance of Natural Resource Taxation in Developing Countries
}

\author{
Michael C. Durst
}

\section{Summary}

This paper explores the administrative challenges posed to developing countries as a result of the increasing emphasis in fiscal regimes for natural resource extraction since the Second World War on income-based taxes, including both corporate income and resource rent taxes, as opposed to royalties. The paper identifies both the political consequences and technical challenges (particularly in the area of enforcement of arm's length pricing in the natural resource context).

Politically, the paper argues that reduced reliance on royalties has clouded the imagery of natural resource taxation as a means of ensuring governments fair market compensation for the alienation of their non-renewable resource endowments, and instead has rendered natural resource taxation increasingly vulnerable to the political scepticism that has surrounded corporate income taxation in recent decades. The greater exposure of natural resource levies to this scepticism appears to have led to high levels of toleration of corporate tax avoidance by governments at all levels of economic development. From a technical perspective, the paper argues that income-based levies are intrinsically far more vulnerable to avoidance than royalties, posing substantial administrative challenges to those developing countries that wish to achieve high levels of tax compliance.

Today, natural resource fiscal regimes around the world typically employ a mixture of royalties and income-based levies; this mixture is intended to afford a balance of protection against financial risks to governments as well as investors. Despite the shortcomings of income-based levies, this paper does not advocate that the practice of mixed fiscal regimes be abandoned. Nevertheless, the paper argues that in the interest of greater administrability, the mix of fiscal instruments might be adjusted to some extent in favour of royalties, especially to the extent royalties include rates that adjust with product prices, so that their incidence correlates to a substantial extent with investors' net income.

In addition, the paper suggests technical means by which developing countries might improve the performance of income-based natural resource levies. In particular, using the Norwegian reference pricing system for North Sea Oil as a model, the paper argues that developing country governments might obtain greater control over revenue losses by adopting 'administrative pricing' regimes. Under these the government, rather than the taxpayer, takes the initiative in establishing arm's-length product prices based on both posted price benchmarks and research into local pricing conditions (including, for example, local variations in product quality, and prevailing industry practices with respect to sales contract duration). Although administrative pricing regimes are now most common with respect to oil and gas, the paper recommends that the use of these regimes be expanded to hard minerals taxation. The paper also explores the extent to which developing country governments might apply principles of administrative pricing not only to the determination of product prices, but also to the arm's-length limitation of related-party expenses for services and supplies, as well as the control of excessive interest expense.

Keywords: natural resources; oil and gas; petroleum; mining; fiscal regimes; transfer pricing. 
Michael C. Durst is a long-time tax practitioner based in the USA, an author on international taxation and developing countries, a former government official and law professor, and a Senior Fellow at the International Centre for Tax and Development. 


\section{Contents}

Summary 3

Acknowledgements $\quad 6$

Acronyms 6

Introduction $\quad 7$

1 The heightened vulnerability of income-based taxation to avoidance 9

1.1 The sobering arithmetic of income-based taxation 9

1.2 Challenges in the valuation of extracted product 10

1.3 The problem of services, supplies and equipment obtained
from related parties

$1.4 \quad$ Interest on loans from related parties 13

$\begin{array}{lll}1.5 & \text { Aggregate revenue losses from profit shifting to tax havens } & 14\end{array}$

2 Political consequences of the shift towards reliance on income-based taxes

2.1 Introduction 15

2.2 Doubts about the advisability of corporate income taxation

2.3 Tax competition 16

2.4 Political imagery and the institution of taxpayer self-assessment 16

3 Possible responses to the vulnerabilities of income-based levies in the extractive sector

$\begin{array}{lll}3.1 & \text { Adjusting the mix between royalties and income-based taxation } & 18\end{array}$

3.2 The administrative pricing model in natural resource revenue administration

$\begin{array}{ll}3.2 .1 & \text { Introduction } \\ 3.2 .2 & 19\end{array}$

3.2.2 The Norwegian system 20

3.3 Administrative pricing for products other than crude oil 21

3.4 Dispute resolution under administrative pricing regimes 22

3.5 Extending the administrative pricing model to related-party expenses 23

3.6 Interest deductions 24

4 Conclusion $\quad 25$

$\begin{array}{lr}\text { Appendices } & 27\end{array}$

References $\quad 32$ 


\section{Acknowledgements}

The author is grateful for the generosity of a number of experts on natural resource taxation who have commented on prior drafts. Much of what may be of value in this paper derives from their contributions; the responsibility for any shortcomings is the author's alone.

\section{Acronyms}

EBITDA Earnings before interest, taxes, debt and amortisation

OECD Organisation for Economic Co-operation and Development

PPB Petroleum Price Board

WTI West Texas Intermediate 


\section{Introduction}

The extraction of a country's natural resources can provide public revenue that is central to the realisation of the country's hopes for economic development. In raising revenue from the extraction of resources, a country's government does not only act in the exercise of its sovereign taxing authority, but also in a proprietary capacity as seller of non-renewable assets on behalf of the country's population. Failures of revenue-raising in the extractive sector are therefore especially regrettable, as they represent the denial of fair compensation for the disposition of the country's endowment of wealth.

Since the end of the Second World War, the nature of fiscal measures that governments use in the natural resource sector has changed, and the change has magnified the difficulties that governments face in administering and enforcing the taxation of natural resource extraction. Historically, governments depended heavily on a particular kind of fiscal instrument royalties - to raise revenue from the extraction of natural resources. ${ }^{1}$ Royalties are usually based on the gross value of the product that is extracted and sold by a miner or driller. ${ }^{2}$ In the post-War decades, however, governments have been relying relatively less on royalties in seeking to generate revenue from extractive operations, and more on various kinds of levies that are based, not on the gross, but instead on the net income that a company derives from the extraction of product. Today, although practices vary, governments typically obtain natural resource revenue from a combination of royalties and income-based levies. The income-based levies used are of several different kinds, including: (i) application to the extractive company of a country's regular corporate income tax; (ii) resource rent taxes or other taxes that are designed to apply only after the extractive company has achieved profitability from its investment; and (iii) production-sharing contracts or other arrangements in which the company and host government agree to divide income that arises from a project. ${ }^{3}$ Sometimes different income-based levies are applied to a particular project simultaneously, typically along with royalties.

The movement towards greater reliance on income-based taxation reflects important considerations of economic efficiency. ${ }^{4}$ Whereas royalties become payable immediately upon the start of extraction of marketable product from a project, income-based levies do not become payable until after the extractive company has begun to realise net profits from its operations. Therefore, by relying relatively less on royalties and more heavily on incomebased levies, a government reduces the extractive company's risk that it will be taxed even on a loss-making investment. This protection is expected to encourage new investment in natural resource development, and lower the costs of inducing extractive companies to participate in the exploitation of a country's resources.

The economic efficiency of income-based taxation when realised, however, is bought at a price. Income-based natural resource taxes are much more difficult for governments to

\section{See Guj et al. (2013: 51).}

e.g. under a royalty of $10 \%$, if a driller extracts and sells oil with a total fair market value of $\$ 10$ million, the driller will owe a royalty of $\$ 1$ million. In practice, not all royalties are based on the value of extracted product. In some cases, especially for low-value products like gravel, royalties might be stated as a particular monetary amount per volume (e.g. per ton or per barrel) of product that is extracted. Sometimes, in addition, countries will label as 'royalties' levies that are based not on gross revenue but on a company's net profits; these levies are in substance forms of income taxation and should be analysed accordingly. Royalties based on gross product value (i.e. ad valorem royalties), however, are the most common form of royalties, and can be taken as paradigmatic for analytical purposes in comparing royalties with income-based taxes.

3 For a concise explanation of production sharing contracts, see Sunley et al. (2002: 7-9). Useful summaries of various kinds of contract between governments and developers in connection with, respectively, oil and gas and hard minerals extraction, are available in Openoil (2012) and International Senior Lawyers Project et al. (2013).

$4 \quad$ The economic advantages of income-based taxation are explained in detail in Boadway and Keen (2010) and Guj et al. (2013). In addition, a useful concise summary is available in Sunley et al. (2002). 
enforce effectively than royalties. The move towards the use of income-based levies has rendered natural resource taxation increasingly vulnerable to the serious problems of revenue erosion that have plagued income-based corporate taxation generally around the world, within and outside the natural resource sector. In part, the elevated vulnerability derives from the basic arithmetic of income-based taxation. As demonstrated by an example in Section 1.1, because income-based taxes are levied not on a taxpayer's gross revenue but instead on the relatively narrow difference (margin) between a company's gross income and its deductible costs, even small understatements by a taxpayer of the market value of extracted products, or small overvaluations of the taxpayer's properly deductible expenses, can reduce the company's tax liability very substantially. The seriousness of this vulnerability is magnified by the fact that extractive companies typically engage heavily in transactions with other members of their multinational groups, in which the companies have substantial opportunity to undervalue gross revenue and overstate the value of properly deductible costs. ${ }^{5}$

In addition, the movement towards greater reliance on income-based taxation in the natural resource sector has exposed natural resource taxation to materially greater political vulnerability. Increased reliance on income-based levies has diluted the imagery of natural resource taxation as a means of ensuring fair compensation in the proprietary sale of a country's non-renewable resources, and has instead elevated the imagery of government acting in the exercise of its general power to tax. Natural resource taxation has therefore become more beholden to: (i) procedural rules and traditions in corporate tax administration that have evolved over many years to constrain governments over-reaching in the exercise of their taxing powers; and (ii) intellectual and political scepticism of the merits of corporate income taxation as a general matter, particularly in the international setting, which has led to widespread toleration of serious dysfunction in the administration of income-based business taxes.

This paper considers ways by which, despite both the intrinsic vulnerability of income-based taxation to erosion and political attitudes that may be hostile to reform, developing countries might reduce revenue losses in the extractive sector. The paper: (i) describes the technical and political difficulties that have accompanied greater reliance on income-based levies in the extractive sector; (ii) explores an administrative pricing model that Norway has used for many years in valuing extracted crude oil for tax purposes, and that other countries have adopted more recently; and (iii) considers ways in which the administrative pricing model might be expanded to the valuation of extracted commodities other than crude oil, and to the valuation of properly deductible taxpayer costs. At several points the discussion identifies areas in which additional country-specific research on tax laws and administrative practices might substantially benefit the design and implementation of reform.

Currently, natural resource fiscal regimes around the world typically include both royalties and income-based levies, in an effort to balance the financial risks of governments and investors. Despite the administrative shortcomings of income-based levies on which it

\footnotetext{
The process of estimating fair market prices in transactions between related parties for tax purposes is usually referred to as transfer pricing. The topic of transfer pricing has been highly controversial in tax policy discussions for many years, with debate often focusing on the question of whether the need to evaluate prices in related-party transactions on a transaction-by-transaction basis imposes unrealistic enforcement demands on tax administrations. Often, discussion of transfer pricing policy centres on whether the current transactional approach should be replaced by a formulary approach, under which taxable income is apportioned among taxing jurisdictions by reference to the relative levels of business activity that multinational groups conduct in different jurisdictions. See generally Avi-Yonah et al. (2009). The ongoing debate over how best to structure transfer pricing laws, however, involves numerous issues that extend beyond the scope of this paper. Also, the formulary approach to transfer pricing, even if it could be made workable for the purpose of international corporate income taxation generally, would for a number of important reasons not be suited for use in the extractive sector - see Dayle Siu et al. (2015). Therefore, to avoid invoking controversies that are not germane to its analysis, this paper generally refers to the pricing of extracted product and deductible expenses in the extractive sector as a process of valuation, and avoids the term transfer pricing unless the context plainly requires otherwise.
} 
focuses, this article is not intended to suggest retreat from the practice of using fiscal regimes that are mixed in this manner. It is suggested, however, that owing to the intrinsic administrative difficulties of income-based levies, the mix of instruments probably should be adjusted to some extent in favour of greater reliance on royalties, especially if royalty rates are structured, as discussed below, so as to vary with product prices. ${ }^{6}$ In addition, the paper argues that substantial administrative improvements should be made to income-based natural resource levies in order to achieve reasonable protection for developing country governments against revenue losses from international base erosion and profit shifting.

\section{The heightened vulnerability of income- based taxation to avoidance}

\subsection{The sobering arithmetic of income-based taxation}

The intrinsic vulnerability of income-based levies to companies' understatements of natural resource product prices can be illustrated by a brief example. ${ }^{7}$ Assume that, during a year, a company extracts ore that would be valued by a neutral and well-qualified appraiser at $\$ 100$ million. If the extracted product is subject to a 10 per cent royalty, then the revenue properly owing to the government is $\$ 10$ million. Assume, however, that the taxpayer reports to the government that the extracted ore has a fair market value not of $\$ 100$ million but of $\$ 92$ million, an understatement of 8 per cent. Because the revenue due under the royalty is directly proportional to the product's fair market value as reported by the company, the government's revenue also falls by 8 per cent - from $\$ 10$ million to $\$ 9.2$ million - for a shortfall of $\$ 800,000$, as a result of the company's understatement.

Assume alternatively, however, that instead of a 10 per cent royalty, the company is subject in its mining operations to an income tax at a rate of 50 per cent. Assume further that the company's annual expenses in its extractive operations are properly valued at $\$ 80$ million. Therefore, if the product for the year is properly valued at $\$ 100$ million, the taxpayer's taxable profit will be $\$ 20$ million, and the properly computed income tax liability will be $\$ 10$ million (the same as the amount of the royalty earlier in this example). Under the income-based levy, however, if the taxpayer values the product at $\$ 92$ million, taxable income is now reduced from $\$ 20$ million to $\$ 12$ million, and the tax is reduced from $\$ 10$ million to $\$ 6$ million, yielding a revenue shortfall to the government not of $\$ 800,000$ but of $\$ 4$ million. Thus, under the income-based tax an 8 per cent understatement of product value has reduced the government's revenue yield not by 8 per cent but by 40 per cent. The arithmetic reason for this result is, of course, readily apparent. Whereas a royalty is applied to the gross value of the product extracted by a taxpayer, an income-based tax is applied to the taxpayer's net profit, which will always be much less than the gross value of the extracted product.

Income-based taxes, therefore, are significantly more vulnerable than royalties to even modest understatements by taxpayers of the value of their gross revenue. Moreover, as discussed further below, whereas the computation of royalties is not affected by the level of a taxpayer's costs, under income-based taxation even relatively small overstatements of deductible costs can substantially reduce a taxpayer's liabilities.

\footnotetext{
$6 \quad$ Keen and Mullins (2017: 34) suggest that recognition of the administrative challenges of income-based taxation 'may ... mean tilting the balance between profit-related taxes and royalties further towards the latter than might otherwise be the case, on the grounds that monitoring deductible costs is harder than monitoring revenues'.

A similar example is found in Clausing and Durst (2015: 11).
} 


\subsection{Challenges in the valuation of extracted product}

It is sometimes thought that the valuation of most kinds of extracted product is a relatively simple and straightforward task, involving reference to posted prices that are publicly available for virtually every kind of commodity. These include, for example, the frequently cited West Texas Intermediate (WTI) and Brent prices for crude oil, and a wide variety of prices for metals and metal ores that are posted daily by the London Metals Exchange and other market clearing houses around the world.

A posted price, however, represents only an approximate starting point for estimating the fair market value of the product that is extracted from a particular mine or field. In order to translate the posted price of any commodity into an estimate of fair market value, it is necessary to adjust the posted price for a number of factors, including: (i) variances in the physical composition of the particular shipment of product (for example, the metal content of different ores, and the presence of impurities like sulphur in crude oil or silica in metals ores) from the benchmark physical composition on which the posted price is based; (ii) the geographic distance of the particular mine or oilfield from the nearest substantial market; and (iii) the contractual terms under which the product is to be sold (which in practice usually will involve agreement for the continued delivery of product for a specified and sometimes extended period of time, rather than the one-time spot purchase terms on which posted prices typically are based). Each of these necessary adjustments from posted prices poses significant technical challenges and requires the exercise of subjective judgement, even for the most seasoned and skillful minerals engineers and other experts. Moreover, the bands of uncertainty surrounding each of these adjustments tend to be large $;^{8}$ taken together, the overall uncertainty as to market price in almost every real-life instance is sufficiently wide, given the arithmetic vulnerability of income-based taxes, to reduce a taxpayer's liability very substantially.

The problem of price uncertainty relating to differences in contractual terms is especially striking. The fair market value of a commodity can be greatly affected by the length of the contract under which the commodity is sold. Contracts for specified terms, as opposed to spot market transactions, contain within them the equivalent of a financial futures contract. The extent to which the pricing of a term contract will differ from the spot market price depends heavily on the historical price volatility of the commodity in question, as well as market expectations of future price movements at the time the term contract is executed. Moreover, in practice long-term mineral contracts vary widely in the extent to which prices per ton or barrel are fixed for the duration of the contract term, or are subject to resetting at specified intervals to reflect changes in spot market prices. Given the infinite range of variability in the durational terms of contracts for the sale of ore, crude oil or natural gas, the estimation of the market price that should properly be included in any particular contract is a matter of wide and speculative judgement. ${ }^{9}$

Although a detailed analysis of the factors that influence natural resource product prices is beyond the scope of this paper, some indication of the volatility of these factors can be found in the variability of some basic pricing indicators. e.g. the daily variation of futures prices of different durations provides an indication of the sensitivity of pricing to the term of a sales contract. See e.g. Barchart, Futures Prices for Iron Ore $62 \% \mathrm{Fe}$ as of 26 July 2016 , <barchart.com/futures/commodities/ITl> (over a 21/2 year period of different maturities, futures price for iron ore varies within a band of $\$ 56.38$ to $\$ 42.05$ per ton, a band of variation of about $25 \%$ ). For discussion of the complexities of valuing iron ore, see Shay (2017: 60-62). Some indication of the variability of product prices to differences in the physical composition and location of product is provided by changes over time in the relationship of Brent and WTI benchmark oil prices. During the period 2010 through 2015, the price premium (annual average) of Brent over WTI varied from a low of 0.2 percent to a high of 18.7 percent. US Energy Information Administration, <https:/www.eia.gov/nav/pet/pet_pri_spt_s1_a.htm>

$9 \quad$ The need for important, and often quite subjective, adjustments to posted prices in order to estimate fair market value suggests that the recent addition of a 'Sixth Method' for valuing natural resources to the OECD's transfer pricing guidelines may be of only limited utility in many cases. (Guidance for application of the Sixth Method is provided at OECD (2015c: 51-54)). The Sixth Method authorises taxpayers and tax administrations to refer to posted prices as probative evidence in determining the fair market value of commodities for tax purposes. Because of the need for adjustments in translating posted prices to fair market value, however, the Sixth Method may provide only a starting 
The vulnerability of income-based taxes to avoidance through the understatement of product prices is greatly magnified by the tax planning practices that multinational natural resource companies have adopted over the decades. Extractive companies that are members of multinational groups virtually never sell product from a mine or well directly to unrelated purchasers in transactions in which actual market prices could be observed. ${ }^{10}$ For example, an iron mining company that is part of a multinational group typically does not sell ore directly from a mine to unrelated steel companies, and an oil production company that is part of a multinational group typically does not sell crude oil directly from a field to an unrelated refiner. Instead, the extractive company first sells the product to a captive marketing company that the multinational group has established in a tax haven country - that is, a country that will not tax the marketing company's profits. The captive marketing company then on-sells the product at a tax-sheltered profit, either to an unrelated refining or trading company or to another subsidiary within the multinational group. The use of the captive marketing company as intermediary in the sale of product is a legal fiction. Although sales of product to and from the captive marketing company are memorialised on paper, the physical product typically is not delivered to the marketing company, but is instead shipped directly from the mine or well to the smelter or refiner. However, because the captive marketing company takes legal ownership, even momentarily, the intermediary role of the marketing company is afforded recognition for tax purposes.

For purposes of this discussion, the key point is that the price at which product is sold from the mine or well to the captive marketing company is not an arm's-length, market-determined price. It is instead a controlled price that is set by the multinational group, typically by its tax department. The group has a large incentive to take advantage of all the relevant uncertainties and to understate the price, thus avoiding taxation in the country where the product was extracted.

\subsection{The problem of services, supplies and equipment obtained from related parties}

Extractive subsidiaries within multinational groups typically procure extensive technical and other services, as well as supplies and equipment, from other group members. For purposes of income-based taxation, taxpayers are permitted to claim deduction of the fair market value of these items. In practice, however, there has historically been a very large amount of controversy between tax authorities and taxpayers over whether taxpayers are claiming excessive deductions for services, supplies and equipment obtained from related parties. ${ }^{11}$

As with sales of extracted product, multinational groups have developed widely used techniques involving the establishment of subsidiaries in tax havens, to magnify opportunities for tax avoidance that exploit uncertainty in the valuation of services and property sold between related parties. ${ }^{12}$ Multinational groups in all industries typically establish what sometimes are labelled hub or principal companies in tax haven jurisdictions. ${ }^{13}$ These companies, at least on paper, serve as intermediaries in purchasing both services and tangible property from members of their multinational group, and reselling them at a taxshielded profit to other members of the group. Under a hub arrangement, the group has a strong incentive to overstate the value of goods and services that subsidiaries purchase from

point for the valuation of product for tax purposes. This is likely to be true especially with respect to the valuation of hard minerals ores, the quality of which can vary significantly even among different shipments from the same mine. See the above footnote.

The tendency for 'first sales' of extracted product to be sold to related parties, with consequent difficulties for revenue administration, has been recognised as a problem for many years. See Gillis (1982: 623).

For extended discussion of this topic, see OECD (2010: ch. VII).

For discussion of the importance of tax haven intermediaries in tax planning in the extractive sector, see Shay (2017: 48-50, 60-63).

United States Congress (2010) describes in detail a number of tax haven-based corporate structures that have been employed by multinational groups. 
other group members, since: (i) the taxable income of the subsidiary that pays for the goods and services is reduced; and (ii) the hub company's profits on the purchase and resale of services and property within the group are sheltered from taxation.

The fair market valuation of services and property transferred among group members is subject to many kinds of uncertainty, which arise primarily from ambiguities in the Organisation for Economic Co-operation and Development's (OECD's) Transfer Pricing Guidelines and other bodies of law governing the issue of valuation for tax purposes. ${ }^{14}$ Among the most important areas of uncertainty are the following:

- The valuation of technical and administrative services. Extractive companies often make substantial use of technical services - for example, drilling and mining engineering services - that are provided by other members of their multinational groups. In addition, subsidiaries within natural resource groups in all industries, including natural resource extraction, make use of a number of administrative services provided by parent companies or other group members, including legal, personnel management and financial services. The law today leaves unresolved several important questions in the tax treatment of related-party services that are of substantial fiscal importance in an era of tax haven hub companies. These questions include: (i) whether the seller of services to other members of its multinational group is entitled to earn a profit from provision of the services, or is entitled instead only to reimbursement of its costs of providing the services; and (ii) if a profit is appropriate, how high it should be. In practice, taxpayers often claim the right to deduct markups on the costs of intragroup services in the range of 8 to 10 per cent; given the arithmetic vulnerability of income-based taxation, the deduction of these markups can substantially reduce the revenue yield of an incomebased tax.

- Insurance services. Often multinational groups establish subsidiaries that purport to provide property and casualty and other insurance coverage to group affiliates located around the world. In any particular case, under applicable tax laws, it can be difficult to determine whether an insurance policy written among commonly-owned companies represents a bona fide insurance service for which the insured company should be permitted to deduct premiums. The practical significance of this question is enhanced by the tax avoidance that is possible when, as is universal in practice, the captive insurance company in question is established in a tax haven, so that the payment of premiums can serve as a convenient means of profit shifting.

- Hedging services. Often natural resource groups find it in their interest to hedge against declines in the price of the commodities in which the group deals. ${ }^{15}$ The hedging can be accomplished in a number of ways, using options, forward contracts and futures, all of which involve some financial cost. Although hedging benefits the multinational group as a whole, a group might claim that the cost of hedging should be allocated to the production companies within the group, thereby reducing those companies' taxable income in the countries where extraction occurs.

- Intangible property. In addition to charging for services, a multinational group may claim that production companies should be liable for deductible royalties for the use of the group's technological know-how - for example, its engineering expertise. The tax avoidance potential of this kind of claim can be magnified by the group's use of a tax haven subsidiary as an asserted holding company for the group's intangible assets.

Although the OECD has studied the question of deductions for related-party expenses intensively in recent years, ${ }^{16}$ transfer pricing laws today do not provide guidance that is

See generally OECD (2010: ch. VII).

Tax issues arising from the hedging activities of extractive companies within multinational groups are discussed in Guj et al. (2013: 56-57) and International Monetary Fund (2012: 45). See also Readhead (2016b: 39-40).

See OECD (2015c). 
sufficient to resolve these uncertainties to any significant extent. The result in practice is that taxpayers resolve the uncertainties in their favour, resulting in substantial erosion of tax revenue.

\subsection{Interest on loans from related parties}

Legal uncertainty concerning the extent to which taxpayers may deduct interest on loans from related parties has led to severe difficulties in enforcing corporate income taxes around the world. In this area as well, multinational groups have magnified opportunities for tax avoidance through a strategy involving the establishment of group finance companies in tax havens. The group contributes large amounts of cash to the finance company, which then extends loans to affiliates around the world. Interest on the loans is deducted in the country of the borrower, yielding reductions in the borrower's corporate tax liability, but there is no corresponding tax burden when the interest is received by the finance company in the tax haven jurisdiction. It costs the multinational group nothing (other than the legal costs of papering the necessary transactions) to engage in a group lending strategy of this kind; the only limiting factor is the extent to which the tax administration of the borrower's country will tolerate the practice. Virtually all large multinational groups today make use of tax avoidance strategies centred on intragroup loans, and the volume of tax avoided around the world by these strategies is substantial. ${ }^{17}$

Although tax avoidance through the use of related-party loans is very common under conventionally structured corporate income taxes, this kind of tax avoidance generally does not arise under resource rent taxation, because resource rent tax laws typically do not allow for the deduction of interest (although given that taxes that are labelled 'resource rent taxes' might be structured in a wide variety of ways, the governing statute should be reviewed to ascertain the treatment of interest deductions in any given instance) (Land 2010: 256). Nevertheless, even where resource rent taxes are used, natural resource fiscal regimes typically provide in addition for the application of a country's traditionally structured corporate tax to extractive industry taxpayers. Consequently, the payment of interest on related-party loans results in serious tax avoidance under the natural resource fiscal regimes of virtually all countries around the world.

Historically, corporate income tax laws have offered tax authorities with little effective means of controlling the proliferation of interest deductions using intragroup lending strategies. Typically, laws have permitted tax authorities to challenge companies' deductions for interest if the taxpayers are overleveraged - that is, if they have incurred levels of debt greater than an unrelated lender would be willing to lend the borrowing company, given the borrower's apparent creditworthiness. In seeking to evaluate a borrower's creditworthiness for purposes of this test, tax authorities have often made reference to the ratio between the principal amount of debt to which the borrower is subject, and the value of its assets - that is, to the borrower's debt-to-equity ratio. In practice, however, determining a company's creditworthiness by reference to its debt-to-equity ratio is a highly subjective endeavour. Also, multinational groups can increase particular subsidiaries' levels of equity, and thereby manipulate their debt-to-equity ratios, through contributions of cash and other liquid assets. For these reasons, in practice tax authorities have not been able to control taxpayers' related-party interest deductions by reference to the traditional test of apparent creditworthiness. ${ }^{18}$

\footnotetext{
17 Tax avoidance strategies involving the use of related-party debt by multinational groups are discussed in detail in OECD (2015b). For a recent comprehensive discussion of this topic, see Fleming et al. (2015).

18 In some situations, notwithstanding the difficulties of using the debt-to-equity ratio as the basis for limitations on interest deductions, use of the ratio might be effective if coupled with controls on the taxpayer's injection of additional equity financing - see footnote 19.
} 
Recently the OECD, recognising the large role that related-party debt has played in corporate tax avoidance around the world, as well as the inadequacy in practice of the traditional creditworthiness test, has recommended that countries follow the lead of Germany and some other countries that have adopted certain 'bright-line' restrictions on the deduction of interest by members of multinational groups. ${ }^{19}$ These rules generally limit deductible interest to a specified percentage of the company's earnings before the payment of interest, taxes, depreciation and amortisation (EBITDA). German-style interest limitations could substantially reduce today's large incidence of tax avoidance through the use of finance companies established in tax havens in all industries, including the extractive industry.

However, for reasons of tax competition that are discussed in Section 2.3, relatively few countries around the world - and very few, if any, of the poorer developing countries - have adopted limitations on interest deductions following the German model. Therefore most countries, especially in the developing world, rely only on the long-discredited debt-to-equity ratio approach in seeking to control tax avoidance through the use of related-party debt. The practical result in those countries is that members of multinational groups, including companies engaged in the extraction of a country's non-renewable resources, are permitted to reduce their taxable income at will through the use of related-party debt.

\subsection{Aggregate revenue losses from profit shifting to tax havens}

With currently available data, it is not possible to estimate the amount of tax that multinational groups avoid each year through the shifting of profits to tax havens, using the three basic kinds of avoidance transactions just outlined. It is clear, however, that the volume of tax avoidance is economically significant among countries at all levels of economic development, and that the consequences of the revenue losses are especially serious in developing countries. ${ }^{20}$ Not only do developing countries depend more heavily on corporate tax revenue than wealthier countries, but they are also likely to be especially prone to the pressures of tax competition that inhibit governments from interfering with companies' tax avoidance practices.

There also can be no question that much of today's tax avoidance through profit shifting to tax havens occurs in the natural resource sector. ${ }^{21}$ Because a high proportion of first sales of oil and gas, and of hard minerals, are made from the mine or well to captive marketing subsidiaries established in tax havens, opportunities for tax avoidance through the undervaluation of extractive product are extremely important in natural resource tax administration. Similarly, the use of technical services, supplies and equipment purchased from related parties is very prominent in extractive operations, and extractive companies are often heavily leveraged with related-party debt.

$9 \quad$ OECD $(2015 b)$

20 The OECD (2015a: 4) says the following:

Although measuring the scope of BEPS [base erosion and profit shifting] proves challenging, the findings of the work performed since 2013 confirm the potential magnitude of the issue, with estimates indicating that the global corporate income tax (CIT) revenue losses could be between 4\% to 10\% of global CIT revenues, i.e. USD 100 to 240 billion annually. The losses arise from a variety of causes, including aggressive tax planning by some multinational enterprises (MNEs), the interaction of domestic tax rules, lack of transparency and coordination between tax administrations, limited country enforcement resources and harmful tax practices. The affiliates of MNEs in low tax countries report almost twice the profit rate (relative to assets) of their global group, showing how BEPS can cause economic distortions. Estimates of the impact of BEPS on developing countries, as a percentage of tax revenues, are higher than in developed countries given developing countries' greater reliance on CIT revenues. In a globalised economy, governments need to cooperate and refrain from harmful tax practices, to address tax avoidance effectively, and provide a more certain international environment to attract and sustain investment. Failure to achieve such cooperation would reduce the effectiveness of CIT as a tool for resource mobilisation, which would have a disproportionately harmful impact on developing countries.

See also International Monetary Fund (2014) (noting special vulnerability of developing countries to revenue losses from base erosion and profit shifting).

$21 \quad$ Beer and Loeprick (2015) estimate that, globally, profit shifting of various kinds reduces the income tax base of the oil and gas sector by between $12 \%$ and $35 \%$, and that non-OECD countries generally appear to be more vulnerable to profit shifting than OECD member countries. 


\section{Political consequences of the shift towards reliance on income-based taxes}

\subsection{Introduction}

In three ways, greater reliance on income-based taxation has amplified the political challenges facing efforts to remedy problems of tax administration in the natural resource sector. First, natural resource fiscal regimes have become increasingly vulnerable to the political consequences of longstanding ambivalence among some academics and policymakers towards the wisdom of corporate income taxation as a general matter. This ambivalence has very likely contributed to a lack of political enthusiasm among fiscal policymakers in a number of countries for measures that might reduce the global incidence of corporate tax avoidance. Second, greater reliance on income-based taxes has rendered natural resource taxation more susceptible to the effects of international tax competition. Third, the shift in political imagery associated with revenue-raising in the extractive sector away from that of government acting in its proprietary capacity and towards that of government acting pursuant to its taxing power - has subjected natural resource taxation increasingly to procedural regimes that have evolved over many years in response to a perceived need to curtail government's administrative effectiveness in the exercise of its taxing powers.

\subsection{Doubts about the advisability of corporate income taxation per se}

Influential academics and policymakers have for many years disagreed about the desirability of corporate income taxation as an instrument for raising public revenue. ${ }^{22}$ On one hand, despite its vulnerability to profit shifting and base erosion, corporate taxation continues to generate revenue that governments would have great difficulty replacing. This consideration is seen as particularly important for developing countries, for whom corporate taxes tend to supply an especially large percentage of total government revenue. ${ }^{23}$ Proponents of corporate taxation also argue that, as much of the burden of corporate tax appears to fall on owners of capital, corporate taxation adds progressivity to tax systems. Opponents argue, however, that corporate income taxes, which are imposed directly on profits derived from corporate investment, tend more intensively than other taxes to discourage investment and thereby suppress global economic growth. It is argued further that considerations of tax competition impose severe constraints on governments' ability to levy corporate taxation successfully, particularly in the international setting. Opponents also question the extent to which the incidence of corporate income tax is in reality progressive, arguing that the economic consequences of corporate income taxation adversely affect workers and consumers as well as corporate shareholders.

Political and intellectual disagreement concerning the substantive merits of corporate income taxation has almost certainly contributed to political resistance to reforms that would increase revenue yields from corporate taxation, including proposals that would curtail the use of tax avoidance techniques like those described above. The criticism of corporate income taxation has also probably resulted in a certain amount of ambivalence towards procedural measures that would enhance the administration and enforcement of corporate tax laws. In view, however, of the special role of natural resource taxation in ensuring fair compensation for the alienation of a country's non-renewable resources, ambivalence towards the value of corporate income taxation generally should not be permitted to impede the enforcement of

For framing of this debate, compare Avi-Yonah (2004) and Brauner (2008).

See footnote 20 . 
corporate income taxes when included as part of a country's fiscal regime for natural resources.

\subsection{Tax competition}

Another important source of political ambivalence towards the reform of corporate income taxation has been the phenomenon of tax competition. ${ }^{24}$ Governments of countries at all levels of economic development see themselves as competitors for inbound investment by multinationals, and in response feel compelled to offer investing companies full or partial relief from taxation. To some extent, governments provide this relief through explicit tax exemptions, often in the form of tax holidays for companies willing to make new business investments within a country. Explicit tax exemptions like tax holidays, however, can invite political criticism, so that often governments provide effective relief less transparently by tolerating, and even tacitly encouraging, rules and practices that leave corporate taxes heavily exposed to taxpayer avoidance.

In view of the large economic rents that natural resource deposits can offer potential investors, it might be thought that the effects of tax competition would be muted in the extractive sector. Few, if any, natural resource discoveries, however, are so economically compelling as to transcend entirely the forces of tax competition. Typically, with respect to any particular commodity at any point in time, companies face a choice of more or less inviting extractive opportunities in which to invest in different countries. The choice among these opportunities can be influenced by differences in the fiscal terms that are offered, and governments often feel strongly beholden to the forces of tax competition even in the field of natural resources. ${ }^{25}$

The influence of tax competition is not limited only to income-based taxes. Instead, one would expect tax competition to reduce governmental willingness to enforce all fiscal instruments as they apply to inbound investors, including royalties. However, because revenue from income-based levies is much more vulnerable than royalties to erosion by profit shifting techniques, governmental acquiescence in porous tax laws and procedures is likely to have more serious adverse effects on revenue yields from income-based fiscal instruments than from royalties.

\subsection{Political imagery and the institution of taxpayer self-assessment}

As natural resource fiscal regimes have moved away from their historical emphasis on royalties and towards greater reliance on income-based taxation, the image of government as the proprietary seller of resources on behalf of the public has faded, and the image of government acting to exercise its taxing powers has gained prominence. ${ }^{26}$ This change in imagery is likely to have contributed to increasing toleration of substantive and procedural rules that impair the effectiveness of tax administration, and particularly enforcement, in the natural resource sector.

\footnotetext{
24 For an important and comprehensive analysis of the political, ethical and economic consequences of tax competition, see Avi-Yonah (2000). For a recent discussion of tax competition focusing on effects in developing countries, see Durst (2016).

25 See generally Boadway and Keen (2010: $60 \mathrm{ff}$ ). Mansour and Swistak (2017) offer an analysis suggesting that extractive industry taxation may be affected less by competitive pressures than taxation in other sectors. This may suggest that governments of resource-rich countries often have sufficient market power to resist competitive pressures - although the authors warn that their analysis should be considered preliminary.

26 International Senior Lawyers Project et al. (2013: 73) encapsulates the traditional imagery of royalties:

The theory behind a royalty is that it is a payment to the state for the mineral resources owned by the state on behalf of the people. A royalty is not, strictly speaking, a 'tax.' It is an exchange for the right to mine. Therefore, royalty provisions are often found in a state's mining law rather than in its tax law.
} 
When a government is seen as the proprietary seller of its country's resources, the behavioural norms most naturally appropriate to the government are those of the marketplace - norms under which sellers are expected to act assertively in proposing asking prices in transactions, and buyer and seller generally are entitled to procedural parity in negotiations. When government is seen as acting pursuant to its taxing powers, however, a different imagery naturally applies. Acting in its taxing capacity, government is viewed as inherently prone to overreaching, and is seen as properly subject to substantive and procedural restraints exceeding those that are appropriate to sellers of goods in the marketplace.

Logically, the shift towards greater reliance on income-based taxation does not change the underlying substance of governmental revenue-raising in the extractive sector. That is, if the government was motivated by proprietary concerns under royalty regimes, it logically remains so motivated under fiscal regimes relying more heavily on income taxes. Moreover, the economic effects of a levy are the same whether the levy is seen as motivated by governmental proprietary interests or by the government's power to tax. Boadway and Keen point out that: 'From the perspective of the investor ... it makes little difference whether a payment is called a royalty or a tax: the economic impact is the same. In terms of policy design too, whether one thinks of a royalty as akin to a user fee or as an explicit tax, the determination of its proper level and time path reduces to the same question in optimal pricing' (Boadway and Keen 2010: 27-28). ${ }^{27}$ Therefore, as a matter of logic alone, the move towards greater reliance on income-based levies should not shift political attitudes towards revenue-raising in the natural resource sphere. ${ }^{28}$

Nevertheless, imagery is a powerful force. As a practical matter, the greater prominence of income-based taxation has subjected natural resource fiscal regimes more heavily to substantive rules and procedural traditions that seriously constrain government's ability to enforce revenue-raising instruments effectively. Whereas the constraints might, at least arguably, reflect an appropriate balance between the interests of governments and taxpayers in many circumstances, they seem unduly restrictive when government seeks to operate in its role as seller of a country's non-renewable resources.

Constraints against governmental overreaching in the exercise of its taxing powers are built deeply into the structure of income tax procedures. At the heart of income tax procedures in many countries is the principle of self-assessment - that is, a taxpayer takes the first step in assessing their tax obligations by reporting to the government, on a self-declaration, the taxpayer's own estimation of their proper tax liability. When taxpayers are faced with uncertainty in the estimation of their proper liabilities, there is a long-established legal tradition to the effect that in making their self-declaration taxpayers are permitted to resolve the uncertainties in their favour, so long as their position falls within the range of possible outcomes that a court might plausibly be expected to reach if the position becomes subject to legal controversy. ${ }^{29}$

27 It might be argued to the contrary that where extractive companies are subject to a country's generally applicable corporate income tax as well as to other levies that are applied only to resource extraction, the corporate income tax should be evaluated for policy purposes separately from the other components of the fiscal regime - and particularly that the corporate income tax component of the fiscal regime should be evaluated by reference to whether the corporate income tax, as applied to resource companies, is similar in incidence and other effects to the corporate income tax as it is applied in the economy generally - see Mintz and Chen (2012). Against this, however, the social welfare implications of government's proprietary role in natural resource taxation arguably are sufficiently compelling to justify greater deference to governmental interests in the natural resource setting than in the field of corporate income taxation generally.

28 The fact that even a levy labelled as a corporate income tax (or resource rent tax) serves the practical purpose of compensation for the alienation of resources points to the need for ring fencing income-based taxes, so that only expenses and losses incurred in the course of a particular extractive project can be used to offset gross income from that project. See generally Calder (2017: 82-83). In practice, ring fencing always plays a large role in the design of fiscal systems for natural resource extraction.

$29 \quad$ For discussion of the roots of this tradition, see Durst (1987). 
After a taxpayer has submitted their self-declaration, it is then up to the tax administration to audit it and to challenge positions that the tax administration believes may be unduly favourable to the taxpayer. The taxpayer then has the opportunity to protest the tax administration's findings on audit, first typically through an administrative appeals process and then, if the matter remains unresolved, in the courts. The principle of permitting taxpayers to resolve bona fide uncertainties to their advantage on their tax declaration is unavoidable under self-assessment tax regimes. To require taxpayers to resolve uncertainties against their own interests would subject taxpayers to pressure, in essence, akin to that of self-incrimination, and would be seen as representing an undue imposition of governmental power over actors in the private sector.

Procedural deference to taxpayers is not limited to the process of filing the taxpayer's selfdeclaration, but extends as well to the resolution of tax disputes. Technically, under the procedural laws in place generally in countries around the world, once a tax authority has asserted an adjustment in the course of an audit, the adjustment is presumed correct unless the taxpayer can refute it by a preponderance of the available evidence. As a practical matter, however, judges, wary of the possibility of governmental overreaching, tend to hold tax authorities to high standards of clarity and persuasiveness in their arguments for adjustments to taxpayer positions. Historically, this tendency has posed serious challenges to tax authorities in disputes involving questions that involve the exercise of subjective judgement, including questions of valuation. ${ }^{30}$ This is true especially in cases involving large amounts of potential tax liability, in which judges typically are presented with conflicting analyses from expert witnesses hired by both taxpayers and the government. Judges often are left with the impression that the government is acting unreasonably, and those cases that come to court are usually decided (to the frequent frustration of government counsel) heavily in the taxpayer's favour (Avi-Yonah 2007; Durst and Culbertson 2003). ${ }^{31}$

Tax authorities, in short, are at a serious procedural disadvantage in seeking to challenge taxpayers' valuations of items of income and expense, and knowledge of this disadvantage has for many years affected tax enforcement practices around the world. Tax authorities typically are willing to devote enforcement resources only to taxpayer valuations that appear grossly biased against the taxpayer. Positions that appear less egregious are either passed over during audits or are resolved in an essentially ritualistic matter in the course of administrative appeals, often on the basis of relatively minor concessions by the taxpayer. ${ }^{32}$

\section{Possible responses to the vulnerabilities of income-based levies in the extractive sector}

\subsection{Adjusting the mix between royalties and income-based taxation}

Although greater reliance on income-based levies has imported serious problems into the administration and enforcement of natural resource taxation, income-based levies also offer important economic efficiencies, ${ }^{33}$ and reversing the trend towards greater reliance on

\footnotetext{
30 The difficulties faced by tax authorities in pursuing controversies involving related-party pricing are described in United States General Accounting Office (1995), and in numerous judicial opinions that are analysed in Avi-Yonah (2007). See also Durst and Culbertson (2003).

31 Two recent US judicial opinions in which this tendency is indicated rather clearly are Veritas v. Commissioner, 133 T.C. 297 (2009), and Medtronic v. Commissioner, T.C. Memo 2016-112 (9 June 2016).

32 Administrative appeals processes around the world typically are shielded from public disclosure by taxpayer confidentiality rules. Therefore, there is little transparency in the manner in which issues of valuation, even very large ones, are resolved in practice. 
income-based taxation should be approached with caution. Most importantly, whereas under a royalty the investor faces the prospect of taxation before the costs of an investment have been recovered, taxation under an income tax begins only after the investment has become profitable - and, under a resource rent tax, only after the investor has not only recovered their costs, but has also achieved at least a minimal return on their overall investment. By mitigating investor risks, income-based taxes generally should lower the costs to countries of attracting extractive industry investment. The cost to low-income countries of forgoing this advantage, by eschewing the use of income-based levies in their fiscal regimes for natural resources, would appear high.

Nevertheless, it does not seem rational to achieve the economic efficiencies of incomebased taxation at the cost of revenue shortfalls that, to a serious extent, deprive a country of fair compensation for the removal of its non-renewable resources. Therefore, despite the political and technical challenges of doing so, the task of improving the performance of income-based levies in the natural resource sector should be seen as both urgent and essential.

As a temporary measure, until effective substantive and procedural reforms can be implemented, countries might wish, at least to some extent, to defer expansion of the use of income-based taxes in their natural resource fiscal regimes. In particular, it might be possible as an interim measure to make greater use of various kinds of progressive royalties. The rate of a progressive royalty adjusts with changes with product prices, production volumes or both, so that the rate of the royalty generally will adjust, albeit roughly, in correlation with the extractive company's net income. Progressive royalties, therefore, provide some of the riskmitigating features of income-based taxes, but do not require the actual measurement of net income, so they are much less vulnerable than income-based taxes to revenue erosion through profit shifting strategies. ${ }^{34}$

Even the most creatively designed progressive royalties may afford investors significantly less protection against risk than income-based taxes, so progressive royalties may not be appropriate as a substitute for income-based taxes in the long term. Their more widespread use, however, would be sensible, at least until the vulnerabilities of income-based instruments can be successfully addressed.

\subsection{The administrative pricing model in natural resource revenue administration}

\subsubsection{Introduction}

An alternative to self-assessment, as a means of handling the valuation issues that arise under income-based taxation, is an administrative pricing approach. ${ }^{35}$ Under an administrative pricing regime the tax authority, rather than the taxpayer, initially provides a valuation with respect to an item of income or expense. The taxpayer typically has the opportunity to consult with the tax authority with respect to the valuation, but the government, as first mover in setting forth an arm's-length price, obtains what amounts to a substantial presumptive advantage - it is the taxpayer that must demonstrate that the government's price determinations fall outside a reasonable range of correctness, rather than the reverse.

$34 \quad$ Guj et al. (2013: 13-16) and Boadway and Keen (2010: 29-30) enumerate various ways in which royalties can be structured. Clausing and Durst (2015) find a strong correlation between oil and gas price levels and the profitability of extractive companies, suggesting that a price-based royalty might to some extent approximate the economic results of an income tax from the standpoint of a natural resource investor.

35 See Guj et al. (2013: 54) and Calder (2010: 348). Calder writes:

Pricing may also be carried out as a separate process from audit. It is a process by which tax authorities determine in advance what prices companies must use for valuing their production when calculating their taxes. This advance pricing procedure is adopted because of the prevalence of transfer pricing risks and other pricing risks in the resource industry ... Pricing of production is clearly crucial, and presents significant risks. 
The taxpayer is afforded the opportunity to appeal valuations with which it disagrees; appeal processes typically rely on arbitration using expert panels.

The discussion below describes an administrative pricing system that Norway has had in place for the valuation of its North Sea crude oil, and which several other countries have incorporated in their regimes for petroleum taxation. The discussion then considers means by which the principles of administrative pricing might be extended to: (i) the valuation of commodities that are more difficult to appraise than crude oil, including metal ores; (ii) the determination of permissible deductions for related-party expenses of various kinds; and (iii) the limitation of interest deductions.

\subsubsection{The Norwegian system}

When large oil deposits were proven under Norway's waters at the end of the 1960s, the country faced several circumstances that were conducive to effective revenue administration. The newly-found deposits were large and potentially very profitable, thus providing some degree of insulation from international tax competition. There was a strong political commitment to ensuring that the public obtained a fair share of proceeds from exploitation of the North Sea fields. Finally, tax avoidance practices involving the use of tax havens in connection with related-party transactions were less globally pervasive than they are today, so multinational companies may have perceived less of a political stake in the status quo with respect to the rules governing valuation for tax purposes.

The result was the establishment in 1976 of a system of 'norm prices' for petroleum, under the jurisdiction of a Petroleum Price Board (PPB), an independent expert body that is housed within the Petroleum and Energy Ministry and includes members from that ministry and the Finance Ministry. ${ }^{36}$ On a quarterly basis, for each North Sea field the PPB establishes provisional daily prices for oil that will be lifted from the field during the forthcoming three months. At the inception of each three-month period, the companies concerned are invited to offer submissions setting forth their views of the appropriate daily price levels, but there is no explicitly adversarial process for setting the prices. The norm prices apply, for tax purposes, ${ }^{37}$ to both related-party sales as well as to any third-party sales that might be made from the fields; this coverage relieves the government of the need to verify the actual independence of transactions that are presented by the taxpayer as occurring between unrelated parties. At the end of the quarter, the PPB adjusts the provisional prices and issues final daily prices for use in tax reporting with respect to each field. Companies can appeal the PPB's price determinations to an appellate board sitting within the Ministry of Finance, and further appeal may be had to the courts. In practice, controversy over the PPB's pricing decisions reportedly has been limited, and the Norwegian pricing system appears now to have operated effectively for about forty years. The PPB's quarterly price determinations for each North Sea field are routinely made available to the public.

36 Regulations governing the Norwegian pricing system are available at $<$ www.npd.no/en/Regulations/Regulations/Normprice-fixing/>. Brief histories of the system are available at <www.regjeringen.no/en/topics/energy/oil-andgas/petroleum-price-board-and-the-norm-price/id661559> and

$<w w w . n o r s k p e t r o l e u m . n o / e n / f r a m e w o r k / n o r w a y s=p e t r o l e u m-h i s t o r y />$. An extended description of the Norwegian system is found in a United States Tax Court opinion, Phillips Petroleum Co. v. Commissioner, 104 T.C. 256 (1995) (court holds that Norwegian taxes are eligible for US foreign income tax credits notwithstanding administrative manner in which oil prices are determined).

When, as under the Norwegian system, administrative pricing regimes apply to income taxes as opposed to royalties, the pricing regime might be subject to legal challenge under bilateral income tax treaties, which generally require countries to follow arm's-length transfer pricing methods (and which do not apply to royalties) (Calder 2017: 80). So long as an administrative pricing regime represents a good-faith effort to estimate market prices, however, the success of a legal challenge based on tax treaties would seem unlikely.

37 Norway depends primarily on income-based taxes in its fiscal regime for petroleum, and does not impose a royalty. See generally Deloitte, Oil and Gas Taxation in Norway,

<http://www2.deloitte.com/content/dam/Deloitte/global/Documents/Energy-and-Resources/gx-er-oil-and-gas-taxguidenorway.pdf>. 
The organising principle of the Norwegian system is that, in setting the quarterly norm prices, the government in effect resolves all of the uncertainties that must be addressed in estimating a market price, including uncertainties as to the effects on market price of variations in product quality, transport costs and contract duration. ${ }^{38}$ None of these parameters is left open to determination through taxpayer self-reporting. This comprehensive coverage of all materially relevant variables is essential because, as illustrated above, uncertainty with respect to even a single variable could generate large revenue losses, given the intrinsic vulnerabilities of income-based taxation.

A number of developing countries have adopted systems of prescribed petroleum pricing for tax and royalty purposes, that are based in some manner on available posted prices. These include Indonesia, ${ }^{39}$ Nigeria ${ }^{40}$ Angola,${ }^{41}$ Mauritania ${ }^{42}$ and Afghanistan. ${ }^{43}$ In view of the apparent promise of the administrative pricing model in addressing difficult questions of valuation under income-based taxation, comprehensive research concerning the effectiveness of the approach in practice would be valuable. Research should aim at the compilation of as complete a catalogue as possible of existing administrative pricing regimes in producing countries at all levels of economic development, ${ }^{44}$ and should compare the details of each country's regime, particularly the extent to which taxpayers are permitted on their own initiative to made adjustments to posted prices for factors like product quality differentials, transportation costs and contract duration. In addition, to the extent feasible under countries' transparency policies and other factors affecting the availability of data, research should include in-depth studies of the operation of different administrative pricing regimes in practice, including the extent of taxpayer compliance, the frequency of disputes, and the extent to which disputes are satisfactorily resolved.

\subsection{Administrative pricing for products other than crude oil}

Crude oil, in part because of its relative uniformity in physical composition, is more susceptible to an administrative pricing regime than other natural resource products. Other products, including hard mineral ores and even natural gas, are generally harder to value in part because of their wide range of physical variability. ${ }^{45}$ Hard minerals extraction, however, is of crucial importance to the economies of many countries, including some of the world's poorest developing countries, and the need for successful techniques of administrative pricing for hard minerals is urgent.

\footnotetext{
$38 \quad$ For purposes of addressing the variable of contract duration, the pricing board seeks to determine average contractual terms as found in the marketplace for product of a particular kind. See Phillips Petroleum v. Commissioner, 104 T.C. at 265.

39 See PricewaterhouseCoopers (2016: 55) and Sunley et al. (2002: 25).

40 The Nigerian national oil company maintains a system of reference prices based on a basket of posted prices along with quality differentials. The extent to which the pricing system applies for tax and royalty purposes (in addition to the pricing of product sold by the national oil company) is unclear. See Nigeria Extractive Industries Transparency Initiative (2013: 34-38, 177-181, 184-187).

41 Angolan Law on Taxation of Petroleum Activities (December 2004). An unofficial translation of the law is available at $<$ http://www.eisourcebook.org/cms/files/attachments/fiscal-design/Angola\%20\%20Petroleum\%20Taxation\%20Law\%202004.pdf>; excerpts are provided in Appendix A.

42 The Mauritanian pricing rules are incorporated in contracts for several exploration and production blocs in Mauritania developed by Kosmos Energy. Copies of the contracts are available through the website of the Extractive Industries Transparency Initiative, <beta.eiti.org >, and on a website that Kosmos Energy maintains for purposes of transparency, $<$ http://www.kosmosenergy.com/responsibility/transparency.php >. A copy of the pricing provisions from the contract for Bloc C8 is provided below as Appendix B.

43 Amu Darya Basin Oil Tender of 2011, Ministry of Mines, Islamic Republic of Afghanistan, available through Extractive Industries Transparency Initiative Website, <beta.eiti.org>. The pricing formula contained in the contract is provided below as Appendix C.

$44 \quad$ According to Sunley et al. (2002: 3 n.4), some countries' fiscal regimes employed government-determined market prices prior to the 1970s but these fell into disuse; the establishment of the Norwegian system represented a reversal of a trend away from administrative pricing. Historical research on this topic would be useful.

45 See e.g. Sunley and Baunsgaard (2001: 14-15) and Calder (2017: 93).
} 
Effective administrative pricing regimes for hard minerals are likely to require continuous onsite inspection and appraisal by assayers or other technical experts employed, or hired on a contract basis, by the tax administration. Government appraisers of extracted product are already used within the hard minerals sector ${ }^{46}$ but useful documentation of different countries' experiences seems difficult to locate. This, too, is an area in which detailed country-specific research could be very helpful.

An approach related to, but not as ambitious as, fully-fledged administrative pricing is a formulaic approach to product valuation similar to that which has been used pursuant to contract by Afghanistan for pricing crude oil, which may be suited for the valuation of some kinds of hard minerals. ${ }^{47}$ Coefficients within a formula might specify the extent to which the posted price for an ore will be adjusted for variations in the physical characteristics of extracted product (for example, by specifying percentage adjustments to posted prices for variations in the concentration of metal, or of specified impurities, within the ore), or for differences in transport costs for particular shipments of ore. The coefficients of the formula might be adjusted only at defined intervals (for example, annually), in contrast to the continuous reassessment of factors affecting product price under a comprehensive administrative pricing system.

Formulas impose less extensive administrative demands than full-scale administrative pricing regimes, and their use is tempting. Commodities markets, however, tend to be both volatile and complex, and the extent to which particular factors of valuation affect the overall product price can change quickly. The financial significance of particular variations in product quality, for example, can shift rapidly as changes in supply and demand alter the relationship between prices of metals of different grade. Also, changes in industry practices as to the duration of the typical sales contract can quickly cause a pricing formula based on fixed coefficients to generate anomalous results.

Fixed formulas might be especially viable in connection with the valuation of high-value commodities like precious metals, because the various adjustments needed to translate posted prices into market valuations are likely to be smaller compared to the intrinsic value of the product. For these products, a formula based on posted prices, and assays of the metal content of each shipment of ore, might provide a stable basis on which to value the extracted product for tax purposes.

Again, detailed country-specific research on different countries' practices for hard minerals valuation is needed. In general, progress towards transparency has been slower with respect to hard minerals than oil and gas extraction, and comprehensive research will pose especially difficult challenges. In view of the importance of hard minerals extraction to many countries' hopes for economic development, however, the need for comprehensive research is compelling.

\subsection{Dispute resolution under administrative pricing regimes}

In order to prevent an administrative pricing regime from degenerating into an unending stream of administrative and judicial controversy, streamlined procedures should be provided for the resolution of disputes. For this purpose, the approach of 'baseball arbitration', of the kind that has been employed in recent years by the United States and Canada for resolving

\footnotetext{
$46 \quad$ Guj et al. (2013: 36) describe, for example, the use of government valuation specialists in connection with the appraisal of extracted diamonds in Western Australia and in Canada.

47 See footnote 43 and Appendix C. Indonesia has employed a formula pricing approach to oil for a number of years, based on posted benchmark prices - see PricewaterhouseCoopers (2016: 55) and Sunley et al. (2002: 25). Research would be useful to evaluate how the Indonesian pricing formula has performed in practice, including the extent to which the formula has accommodated adjustments to posted prices for items like transportation and quality differentials.
} 
bilateral transfer pricing disputes, ${ }^{48}$ might offer promise. Under baseball arbitration both parties submit to the arbitrators their own estimates of the proper price, and the arbitrators are constrained to accept what they find to be the more nearly correct of the two proposals that have been submitted. Baseball arbitration guards against the pursuit of unreasonable positions by either party, and would appear well-suited to the resolution of disputes concerning natural resource pricing.

\subsection{Extending the administrative pricing model to related-party expenses}

The administrative pricing model cannot be extended in its entirety to the determination of permissible levels of deduction for services and property purchased from related parties, because the proper level of deductions will always depend on facts unique to the particular taxpayer. Therefore, deductions for related-party expenses will need to remain subject, at least to some extent, to self-reporting by the taxpayer and after-the-fact audit by the tax administration. Nevertheless, it may be possible to achieve substantially improved revenue results through rules that afford definitive answers to some of the legal uncertainties that currently prevent effective tax administration with respect to related-party expenses.

Especially in recent decades, taxpayers have come to depend heavily on these uncertainties for large amounts of corporate tax avoidance, and as a political matter it might be difficult to prescribe rules for resolving them for application in all industry settings. In view, however, of the special role of natural resource fiscal regimes in ensuring governments fair consideration for the alienation of their non-renewable resource endowments, it might be possible to establish these rules specifically for use in natural resource taxation. Countries might accomplish this either through statutes that apply only to income-based taxation in the extractive industry setting, or by incorporating the rules in concession agreements or other contracts governing resource extraction.

In particular, countries might adopt the following principles for application in extractive industry taxation:

- Disallow deduction of profits accruing to tax haven hubs. A key question is whether extractive companies should be permitted to deduct only reimbursements of a provider's actual fully-absorbed costs of providing technical, management and other services, or whether the extractive company should be permitted in addition to deduct a markup (profit element) on the service-provider's costs. The OECD Transfer Pricing Guidelines generally allow for the deduction of a profit element, but that creates a large risk of the diversion of profits to tax haven hub companies. ${ }^{49} \mathrm{~A}$ rule disallowing the deduction of markups in all circumstances would probably be seen as politically unacceptable, even if applicable only to taxation in the extractive sector. ${ }^{50} \mathrm{~A}$ perhaps more promising alternative for use in the extractive sector is generally to allow the deduction of markups at levels that are consistent with the principles of the OECD Transfer Pricing Guidelines,

See United States Internal Revenue Service, Arbitration Board Operating Guidelines, available a <https://www.irs.gov/pub/irs-utl/2010_-_arbitration_-_board_operating_guidelines_nov_8-10_final.pdf>. See footnote 11 and accompanying text.

Arguably, under income taxation blanket prohibitions of the deduction of markups on service cost would be subject to challenge as violating the requirement, under income tax treaties, that governments apply arm's-length transfer pricing methods; cf. Calder (2017: 80). Income tax treaties do not, however, apply to the terms of production sharing contracts between national oil companies and private extractive companies, and prohibition of the deduction of markups can be found in these agreements (Calder 2017: 99); see e.g. Timor-Leste Model Production Sharing Contract, paragraph 3.4(b)(ii), available at <http://www.laohamutuk.org/Oil/PetRegime/PSC\%20model\%20270805.pdf>.

Although governments probably do not have as much legal latitude as they do under production sharing contracts to depart from arm's length practices with respect to the limitation of companies' expense deductions, production sharing contracts nevertheless can offer useful guidance for the drafting of effective limitations on deductions under incomebased tax rules. While production sharing contracts are much more common with respect to oil and gas than hard minerals, current practices under production sharing contracts may be instructive in designing limitations on deductible expenses in the hard minerals sector. 
but only if the taxpayer certifies that none of the amounts deducted inure directly or indirectly to legal entities that do not physically perform the services that are provided. This approach should generally preclude profit shifting through the use of tax hub companies established in tax havens.

- Hedging and related-party insurance. No deduction should be allowed for hedging services or for factoring services provided by any party, whether or not related to the taxpayer. ${ }^{51}$ No deduction should be allowed for insurance services provided directly or indirectly by a related party. Deduction for insurance services provided by an unrelated party shall be allowed only at cost (that is, on a pass-through basis without markup if the services are procured through the intermediation of a related party).

- Acquisition of equipment and supplies from related parties. Amounts paid for new (that is, not previously used) items sold or leased to an extractive company from a related party should be deductible (or capitalisable, if appropriate) at the price indicated on a purchase receipt from the party from which the property was originally procured. That is, no markup on the original cost of the items should be deductible by the extractive company that receives the property. Deduction of the costs of previously-used items, like used vehicles and mining equipment, generally should be permitted only on the basis of a valuation by a qualified independent appraiser. ${ }^{52}$

- Intangible property. No deduction should be allowed for amounts paid to a related party for the use of intangible property in extractive operations, except that the costs of intangible property procured by a related party from an unrelated party, and then made available for use by the taxpayer, may be deducted to the extent of the actual cost of the intangible property, without markup. This rule is necessary because of the difficulty of distinguishing bona fide licences of intangible property, like proprietary know-how, from the provision of services by expert personnel within multinational groups. Allowance of deductions for items like a group's accumulated technological know-how would permit easy avoidance of rules limiting the deduction of markups on the cost of intragroup services, and could facilitate avoidance through the use of tax haven hub companies.

\subsection{Interest deductions}

Developing countries should, as a general matter, adopt recent recommendations of the OECD and limit taxpayers' related-party interest deductions under the corporate income tax to a ceiling of 10 to 30 per cent of the taxpayer's EBITDA. ${ }^{53}$ Ideally, legislation should apply these rules to corporate taxpayers in all industries. That may meet substantial political opposition, however, and it may be more feasible for governments to apply limitations on interest deductions specially with respect to income from extractive industry projects. This might be accomplished either through statutes that apply specifically to extractive industry

\footnotetext{
51 If a member of a multinational group conducts bona fide hedging operations within a country, it might be appropriate under arm's-length principles to allow deduction of costs related to the hedging within that country - but the hedging activities should be considered an activity separate from any extractive operations that might be conducted within the country and the hedging should be ring-fenced, for purposes of taxation, from the extractive activities - e.g. Guj et al. (2013: 56-57); International Monetary Fund (2012: 45).

52 If an extractive company purchases property that has been manufactured or constructed by another member of the company's multinational group, deductions should be limited to the fully absorbed costs of manufacture or construction plus an arm's-length markup, although no deduction should be allowed for amounts inuring to tax haven companies that did not manufacture the property (e.g. to tax haven companies that have merely purchased and re-sold the property). See Calder (2010: 328) and International Monetary Fund (2012: 45) (supporting the use of simplified limitations on interest deductions in the natural resource setting). The rules adopted by developing countries should incorporate the various technical features recommended by the OECD, including allowance of carryovers of unused deductions, and perhaps the allowance of certain exceptions if the taxpayer demonstrates that its multinational group as a whole deducts interest, on loans from third parties, at levels in excess of the generally applicable EBITDA limitation - see generally OECD (2015b). As a practical matter, statutory limitations on interest deductions generally have been accepted around the world as consistent with provisions in income tax treaties calling for arm's-length transfer pricing rules. cf. Fleming et al. (2015: 701-708); OECD (2015b) (discussing potential EU treaty issues arising from interest limitations, but not raising concerns under bilateral income tax treaties).
} 
income, or by the inclusion of limitations in contracts governing the operation of particular projects. ${ }^{54}$

\section{Conclusion}

Over the course of seven decades, natural resource taxation around the world has come to rely relatively less on royalties and more on income-based forms of taxation. The shift towards income-based taxation has brought with it important economic efficiencies. Increased reliance on income-based taxes, however, has rendered natural resource fiscal regimes much more vulnerable to tax avoidance based on taxpayer exploitation of difficulties in the fair market valuation of items of income and deduction. This kind of tax avoidance, which has received widespread public attention in recent years, is common in all industries. Tax avoidance in the natural resource industry is especially regrettable, however, as it can deprive some of the world's poorest developing countries of fair compensation for the removal of their non-renewable resource endowments.

This paper has suggested that certain principles of administrative pricing, as exemplified by procedures that Norway applies in valuing North Sea oil, might be effective in curtailing various kinds of tax avoidance in the extractive sector. Designing and implementing effective controls on tax avoidance based on the administrative pricing approach will, however, require substantial efforts on the part of researchers, policymakers and advocacy organisations in the international development community.

First, designing and implementing effective controls on avoidance would be assisted by research to identify, evaluate and compare the effectiveness of different countries' current practices in the field of natural resource tax administration. This research should include not only the review of statutes, regulations and contracts, but also observation of revenue administration processes in the field. Performing this research, and publishing the results in usable form, will require a growing commitment on the part of governments to transparency with respect to administrative practices affecting natural resources.

Second, the implementation of effective controls on tax avoidance in the extractive sector should be supported by political efforts to demonstrate the ethical imperative of ensuring tax compliance in the extractive sector. In particular, it will need to be argued effectively that the necessity of ensuring countries fair compensation for the alienation of their non-renewable resource endowments justifies anti-avoidance measures that might not be seen as politically acceptable in other industry settings.

Important research and advocacy in support of improvements to revenue administration in the extractive sector are already being provided from a number of sources. Civil society organisations have been engaged in documenting the damage to social welfare that arises from failure to ensure developing countries with adequate compensation for the removal of their non-renewable resources. ${ }^{55}$ Intergovernmental organisations like the International

54 e.g. Article 14 of the amended concession agreement between the Government of Liberia and Mittal Steel limits the concessionaire's debt-to-equity ratio to 3-to- 1 . The agreement is available at <http://www.leiti.org.Ir/uploads/2/1/5/6/21569928/52423536-an-act-ratifying-the-amendment-to-the-mineraldevelopment-agreement-mda-dated-august-17-2005-between-the-government-of-liberia_and_mittal_steel.pdf>. The use of a rule based on the taxpayer's debt-to-equity ratio generally would be more susceptible of taxpayer manipulation than a German-style rule based on a percentage of the taxpayer's EBITDA - see Section 1.4. If, however, a contract includes safeguards against manipulation of the taxpayer's debt-to-equity ratio by 'stuffing' a legal entity with equity contributions, then a limitation based on the ratio might be sufficiently reliable.

$55 \quad$ See e.g. ActionAid UK (2015); International Mining for Development Centre (2014); Readhead (2016a and 2016b) (studies for Natural Resource Governance Institute); Open Society Initiative for West Africa (2015); and Hubert (2016) (study for Oxfam). In addition, the Extractive Industries Transparency Initiative (EITI), an organisation comprised of companies and industry organisations, governments, intergovernmental organisations and civil society organisations, 
Monetary Fund, World Bank and OECD, as well as a number of national governments, have long been active in seeking to identify effective mechanisms for reform, and in attempting to implement them through technical assistance around the world. Continuing efforts of these kinds are essential if the people of developing countries, including some of the world's most impoverished, are to receive fair compensation for the removal of their irreplaceable endowments of resource wealth. 


\section{Appendices}

\section{Appendix A}

\section{Excerpts from Republic of Angola, Law on Taxation of Petroleum Activities (2004) (English translation by law firm of Miranda, Correia, Amendoeria \& Associados)}

\section{Article 6.1}

1. For the purposes of assessing the taxable income relating to the tax charges referred to in this Law, excluding the Surface Fee, the crude oil produced shall be valued at the market price calculated on the basis of the actual FOB prices obtained through arm's length sales to third parties in accordance with the rules set forth in the following subparagraphs:

(a) The State Concessionaire and each of its associates shall separately submit to the Ministry of Petroleum, at least 15 days prior to the beginning of each quarter, an informative report addressing their forecasts for world supply and consumption of petroleum, and their estimates of the market prices which can be obtained for the crude oil to be produced in their respective concession during the quarter in question;

(b) Within 15 days following the end of each quarter, or by another subsequent date as may be determined by the Ministry of Petroleum, the State Concessionaire and each of its associates shall separately submit to said Ministry formal reports including the actual prices obtained in their respective arm's length sales to third parties, distinguishing between term sales and spot sales. Said reports shall provide a detailed account of sales volumes, buyers, prices received, credit terms and density adjustments. They shall also include the actual calculations of volumetrically weighted average prices on a comparable basis of density and terms of credit. The State Concessionaire and its associates may also provide any further market-related informative data they consider relevant to substantiate the veracity of the information provided;

(c) The Ministry of Petroleum shall examine the data provided, as well as any other trustworthy data which reflect market conditions and which the Ministry considers may be useful in determining a suitable market price for the crude oil sold during the quarter in question. If necessary, the Ministry can meet separately with the State Concessionaire and each of its associates in order to discuss all relevant information which has been provided or which is otherwise available. The data provided, as well as any trustworthy additional data reflecting market conditions, if the latter exists, shall be the sole criteria used to determine market price;

(d) The Ministry of Petroleum and the Ministry of Finance shall analyse the data referred to in the preceding subparagraphs and shall jointly determine the market price, which must be communicated to the State Concessionaire and its associates within 15 days following the presentation of the reports mentioned in subparagraph (b) above;

(e) In the event that neither the State Concessionaire nor its associates have made arm's length sales to third parties during the quarter, the reports of the State Concessionaire and its associates shall be limited to the data relevant to market conditions. The aforementioned Ministries shall in this case determine the market price using the same method described in subparagraph (c) above;

(f) In the event that the State Concessionaire or any of its associates considers that the market price determined under the terms of the preceding subparagraphs does not reflect relevant market conditions, they may individually or jointly, within 20 days of being notified of 
the determined market price, request a second separate meeting with the Ministries of Petroleum and Finance and submit any additional information which they may consider relevant to the matter in question. Within 10 days of having received the aforementioned additional information, and having taken said data into consideration, the Ministries of Petroleum and Finance shall either revise the determined market price, or shall confirm the previously determined market price, providing a duly substantiated explanation;

(g) Should the State Concessionaire or any of its associates consider that the price determined by way of the analysis provided for in the preceding subparagraph still does not reflect market conditions, the matter may be submitted to an independent expert, to be appointed within 15 days, under the terms of subparagraph (i) below;

(h) The expert must prepare and submit a report on the market values for the quarter in question. This report shall include the determination of a fair market value for the crude oil produced in the area in question, and said determination shall be presented to the Ministries of Petroleum and Finance for forwarding to the State Concessionaire and its associates. Within 10 days of having received said report, the State Concessionaire and its associates shall meet jointly with the Ministries of Petroleum and Finance in order to discuss this new information with a view to agreeing upon a mutually acceptable price. In the event they are unable to reach such an agreement, the aforementioned ministries, taking into account the report of the independent expert, shall either proceed to revise the determined price, or confirm the previously determined price, providing a duly substantiated explanation;

(i) The expert shall be an independent and impartial individual or entity, and be appointed by agreement between the State Concessionaire and its associates or, in the absence of such an agreement, shall be appointed within a period of 20 days by a qualified official of a specialised international institution, at the request of the State Concessionaire or any of its associates. The terms of reference provided to the expert shall be such as to require him to submit his report to the Ministries of Petroleum and Finance within 20 days of receiving the matter for consideration. The expert shall take into account all relevant information which may be provided to him by the State Concessionaire, by its associates, or by the Ministries of Petroleum and Finance, as well as information that he may reasonably request from the State Concessionaire or its associates, to be provided to him from their records, or which he may obtain from other available trustworthy sources. Any fees and expenses of the international institution or the expert shall be borne by whosoever submits the case to the latter. 


\title{
Appendix B
}

EXPLORATION AND PRODUCTION CONTRACT BETWEEN THE ISLAMIC REPUBLIC OF MAURITANIA AND KOSMOS ENERGY MAURITANIA

\author{
Bloc C8
}

(April 5, 2012)

\section{ARTICLE 14: PRICE AND MEASUREMENT OF HYDROCARBONS}

14.1 The unitary market price of the Crude Petroleum used in consideration for purposes of Articles 10 and 11 here above shall be the 'Market Price' F.O.B. the Delivery Point, expressed in Dollars per Barrel, as determined here below for each Quarter.

A Market Price shall be established for each type of Crude Petroleum or blend of Crude Petroleums.

14.2 The Market Price applicable to Crude Petroleum lifted in the course of a Quarter shall be calculated at the end of each Quarter under consideration, and shall be equal to the weighted average of prevailing prices obtained by the Contractor and the State in the course of their sale of Crude Petroleum to Third Parties in the course of the Quarter under consideration, adjusted as appropriate to reflect differentials in quality and density, and on the terms of F.O.B. delivery and payment terms provided the quantity sold in such manner to Third Parties in the course of the Quarter under consideration corresponds to no less than thirty per cent $(30 \%)$ of the total of the volumes of Crude Petroleum extracted from the Exploitation Perimeters existing under this Contract, taken as a whole, and sold in the course of the said Quarter.

14.3 If such Third Party sales do not take place during the Quarter under consideration, or if they constitute less than thirty per cent of the total of the quantities of Crude Petroleum of the Exploitation Perimeter granted under the present Contract taken as a whole and sold in the course of the said Quarter, the Market Price shall be arrived at by comparison with the « Current International Market Price » for the Quarter under consideration of the qualities of Crude Petroleum produced in Mauritania and in neighboring producing countries, taking into account differentials of quality, density, transport and terms of payment.

«Current International Market Price » shall be a reference price based on Dated Brent prices, as such are published in 'Platt's Crude Oil Marketwire' or similar internationally recognised publication, averaged for the month(s) during which sales were made and adjusted for differences in quality, API gravity, terms of FOB delivery and payment terms. If Dated Brent is replaced by another internationally recognised reference crude, the published quotes of the replacement crude shall be used instead.

14.4 In particular the following transactions are not taken into account in calculating the Market Price of the Crude Petroleum:

a) Sales in which the buyer is an Affiliated Company of the seller as well as sales between entities making up the Contractor; 
b) Sales which include some consideration other than payment in freely-convertible currency or sales attributable in whole or in part to motivations other than the usual economic incentives attached to sales of Crude Petroleum on the international market (such as barter contracts, sales from government to government or to governmental units).

14.5 A committee presided over by the Minister or his delegate and including other representatives of the State and those of the Contractor shall meet at the request of its president, at the end of each Quarter, to establish, according to the stipulations of this Article 14, the Market Price of the Crude Petroleum produced, applicable to the Quarter elapsed. The decisions of the committee shall be by unanimous vote.

If no agreement can be reached by the committee on a decision within a time period of thirty (30) days after the end of the relevant Quarter, the Market Price of the Crude Petroleum produced shall be definitively determined by an expert of international reputation, appointed by agreement of the Parties, or, if such agreement is not reached, by the International Centre for Expertise of the International Chamber of Commerce. The expert shall establish the price according to the stipulations of this Article 14 within a time period of twenty (20) days after his appointment. The costs of expertise shall be shared equally between the Parties.

14.6 While awaiting the determination of the price, the Market Price provisionally applicable to a Quarter shall be the Market Price of the preceding Quarter. Any necessary adjustment shall be made not later than thirty (30) days after the determination of the Market Price for the Quarter under consideration.

14.7 The Contractor shall measure all the Hydrocarbons produced after extraction of water and connected substances, in utilising, with the consent of the Ministry, the instruments and procedures in conformity with the methods in force in the international petroleum industry. The Ministry shall have the right to examine such measures and to check the instruments and procedures utilised.

If during the course of exploitation the Contractor wishes to modify such instruments and procedures, he must obtain the prior consent of the Ministry.

If, during the course of an inspection carried out by the Ministry, it is verified that the measuring instruments are inaccurate and exceed the acceptable tolerances, and that this condition of fact is confirmed by an independent expert, the inaccuracy in question shall be considered as having existed for half of the period since the preceding inspection, unless a different period is demonstrated. The accounting of the Petroleum Costs and the shares of production and liftings of the Parties shall be the subject of appropriate adjustments within thirty (30) days following receipt of the expert's report.

14.8 For Dry Gas, the provisions of this Article 14 shall apply mutatis mutandis, subject to the provisions of Article 15 here below. 


\section{Appendix C}

\section{Amu Darya Basin Oil Tender of 2011, Ministry of Mines, Islamic Republic of Afghanistan}

11.1 Formula Price for Liquid Hydrocarbons. The Formula Price for the Liquid Hydrocarbons produced and saved from any Field in the Contract Area in any Month shall be determined in accordance with the following formula:

$$
P=U+(B-U){ }^{*}\left(1+0.15139 * A_{P-B}-0.1434{ }^{*} S_{P-B}-T-D\right.
$$

Where

$\mathrm{P} \quad$ is the price of the Liquid Hydrocarbons produced and delivered to the Delivery Point (US\$ per Barrel);

$U$ is the average of the Platt's Prices of Urals crude oil for the Month in question (US\$ per Barrel);

$B$ is the average of the Platt's Prices of Dated Brent crude oil for the Month in question (US\$ per Barrel);

$A_{P-B}$ is the difference between the API degrees of the Liquid Hydrocarbons produced and 38.3 degrees;

$\mathrm{S}_{\mathrm{P}-\mathrm{B}}$ is the difference between the percentage of Sulphur content of the Liquid Hydrocarbons produced and 0.4 per cent;

$\mathrm{T} \quad$ is the deemed transport cost of the Liquid Hydrocarbons produced (US\$ per Barrel), determined in accordance with Section 11.3; and

$D$ is the amount of the initial production discount (if any) on the price of the Liquid Hydrocarbons produced (US\$ per Barrel), determined in accordance with Section 11.4 .

For purposes of calculating the average monthly Platt's Price, the Platt's Price for any Day of the Month means (i) in the case of Dated Brent crude oil, the average of the high and low spot prices for such crude oil as quoted for such Day in Platt's Crude Oil Marketwire (Spot Assessment Section, Dated Brent Assessment) and (ii) in the case of Urals crude oil, the average of the high and low spot prices for such crude oil as quoted for such Day in Platt's Crude Oil Marketwire (Spot Assessment Section, Urals MED Assessment). Transportation costs shall be reviewed every two (2) Years after the Initial Exploration Period according to Section 11.3, and the other coefficients and parameters in the Formula Price shall be reviewed by the Parties at the conclusion of the Initial Exploration Period and then every four (4) years thereafter.

11.3 Transport Costs. During the Initial Exploration Period, $T$ in the formula set forth in Section 11.1 shall have a value of five US Dollars (US\$ 5.00) per Barrel for Liquid Hydrocarbons produced from each Field in the Bazarkhami and Kashkari Blocks and seven US Dollars (US\$ 7.00) per Barrel for Liquid Hydrocarbons produced from each Field in the Zamarudsay Block. Thereafter, the Parties shall meet at least once every two (2) Years to negotiate in good faith any adjustments to $T$ that may be appropriate based upon then prevailing conditions regarding transportation costs for Liquid Hydrocarbons originating from each Field and the applicable Delivery Point for use in determining the Formula Price. 


\section{References}

ActionAid UK (2015) An Extractive Affair, available at $<$ https://www.actionaid.org.uk/sites/default/files/tax_report_-_an_extractive_affair.pdf>

Avi-Yonah, R. (2007) The Rise and Fall of Arm's Length, University of Michigan Law School, Law and Economics Working Papers Archive, available at

$<$ http://repository.law.umich.edu/cgi/viewcontent.cgi?article=1074\&context=law_econ _archives

- (2004) 'Corporations, Society and the State: A Defense of the Corporate Tax,' 90 Va. L. Rev. 1193

(2000) 'Globalization, Tax Competition, and the Fiscal Crisis of the Welfare State', 113 Harvard L. Rev. 1573

Clausing, K. and Durst, M. (2009) 'Allocating Business Profits for Tax Purposes: A Proposal to Adopt a Formulary Profit Split', 9 Florida Tax Rev. 497

Beer, S. and Loeprick, J. (2015) Taxing Income in the Oil and Gas Sector - Challenges of International and Domestic Profit Shifting, Vienna University International Taxation Research Paper Series No. 2015-18

Boadway, R. and Keen, M. (2010) 'Theoretical Perspectives on Resource Tax Design', in P. Daniel, M. Keen and C. McPherson (eds.), The Taxation of Petroleum and Minerals: Principles, Problems and Practice,Abingdon and New York: Routledge

Brauner, Y. (2008) 'The Non-Sense Tax: A Reply to New Corporate Income Tax Advocacy', Mich. St. L. Rev.

Calder, J. (2017) 'Transfer Pricing - Special Extractive Industry Issues', in P. Daniel, M. Keen, A. Swistak and V. Thuronyi (eds), International Taxation and the Extractive Industries, New York and London: Routledge

(2010) 'Resource Tax Administration: The Implications of Alternative Policy Choices," in P. Daniel, M. Keen and C. McPherson, eds., The Taxation of Petroleum and Minerals: Principles, Problems and Practice, New York and London: Routledge

Clausing, K. and Durst, M. (2015) A Price-Based Royalty?, Working Paper 41, Brighton: International Centre for Tax and Development

Dayle Siu, E., Picciotto, S., Mintz, J. and Sawyerr, A. (2015) Unitary Taxation in the Extractive Industry Sector, ICTD Working Paper 13, Brighton: International Centre for Tax and Development

Durst, M. (2016) 'Self-Help and Altruism: Protecting Developing Countries' Tax Revenues', in T. Pogge and K. Mehta (eds), Global Tax Fairness, Oxford: Oxford University Press

__ (1987) 'The Tax Lawyer's Professional Responsibility', 39 U. Florida L. Rev. 1027

and R. Culbertson (2003) 'Clearing Away the Sand: Retrospective Methods and Prospective Documentation in Transfer Pricing Today', 57 Tax L. Rev. 37 
Fleming, C. Jr., Peroni, R. and Shay, S. (2015) 'Getting Serious about Cross-Border Earnings Stripping: Establishing an Analytical Framework', 93 North Carolina Law Review 673

Gillis, M. (1982), 'Evolution of Natural Resource Taxation in Developing Countries', Natural Resources Journal 22(3): 619-648

Guj, P., Bocoum, B., Limerick, J., Meaton, M. and Maybee, B. (2013) How to Improve Mining Tax Administration and Collection Frameworks, Washington DC: The World Bank

Hubert, D. (2016) Mapping Risks to Future Development of Petroleum Revenues in Kenya, Oxfam, available at $<$ https://www.oxfam.org/sites/www.oxfam.org/files/file_attachments/rr-mapping-riskspetroleum-revenues-kenya-060516-en.pdf>

International Mining for Development Centre (2014) Transfer Pricing in Mining: An African Perspective, available at <http://im4dc.org/wp-content/uploads/2013/07/Transferpricing-in-mining-An-African-perspective-A-briefing-note1.pdf>

International Monetary Fund (2014) Spillovers in International Corporate Taxation, Policy Paper, available at <www.imf.org/external/np/pp/eng/2014/050914.pdf>

- (2012) Fiscal Regimes for Extractive Industries: Design and Implementation (August 15, 2012), available at <http://www.imf.org/external/np/seminars/eng/2015/natrestax/pdf/mullins.pdf>

International Senior Lawyers Project, OpenOil, Revenue Watch Institute - Natural Resource Charter, and Vale Columbia Center on Sustainable International Investment (2013) Mining Contracts: How to Read and Understand Them, available at $<$ https://eiti.org/sites/default/files/documents/mining-contracts-how-to-read-andunderstand-them.pdf>

Keen, M. and Mullins, P. (2017) 'International Corporate Taxation and the Extractive Industries: Principles, Practice, Problems', in P. Daniel, M. Keen, A. Swistak and V. Thuronyi (eds), International Taxation and the Extractive Industries, New York and London: Routledge

Land, B. (2010) 'Resource Rent Taxes: A Re-Appraisal', in P. Daniel, M. Keen and C. McPherson (eds), The Taxation of Petroleum and Minerals: Principles, Problems and Practice, Abingdon and New York: Routledge

Mintz, J. and Chen, D. (2012) Capturing Economic Rents from Resources through Royalties and Taxes, University of Calgary School of Public Policy Research Papers, Vol. 5, Issue 30

Mansour, M. and Swistak, A. (2017), "Tax Competition and Coordination in Extractive Industries', in P. Daniel, M. Keen, A. Swistak and V. Thuronyi (eds), International Taxation and the Extractive Industries, New York and London: Routledge

Nigeria Extractive Industries Transparency Initiative (2013) Physical and Process Audit Report for the Period 2009 to 2011, available at $<$ http://neiti.org.ng/sites/default/files/pdf_uploads/EITI-Physical-And-Process-FinalAudit-Report-2009-2011.pdf> 
OpenOil (2012) Oil Contracts: How to Read and Understand Them, available at $<$ http://openoil.net/contracts-booksprint/>

Open Society Initiative for West Africa (2015) Domestic Resource Mobilisation in West Africa: Missed Opportunities, study authored by Dalberg Global Development Advisors, available at <http://www.osiwa.org/wpcontent/uploads/2015/06/DOMESTIC-RESOURCE_ENGLISH-10032915.pdf>

OECD (2015a) Explanatory Statement, OECD/G20 Base Erosion and Profit Shifting Project, OECD, available at <http://www.oecd.org/tax/beps-explanatory-statement-2015.pdf>

- (2015b) Limiting Base Erosion Involving Interest Deductions and Other Financial Payments, Action 4 - 2015 Final Report, Paris: OECD Publishing

(2015c) Aligning Transfer Pricing Outcomes with Value Creation, Actions 8-10 - 2015 Final Reports, Paris: OECD Publishing

- (2010) OECD Transfer Pricing Guidelines for Multinational Enterprises and Tax Administrations 2010, Paris: OECD Publishing

PricewaterhouseCoopers (2016) Oil and Gas in Indonesia, $7^{\text {th }}$ edition, available at $<\mathrm{https}: / /$ www.pwc.com/id/en/energy-utilities-

mining/assets/May\%202016/PwC\%20Indonesia-oil-and-gas-guide-2016.pdf>

Readhead, A. (2016a) Transfer Pricing in the Extractive Sector in Tanzania, Natural Resource Governance Institute, available at $<$ http://www.resourcegovernance.org/sites/default/files/documents/nrgi_tanzania_tran sfer-pricing-study.pdf>

(2016b) Preventing Tax Base Erosion in Africa: A Regional Study of Transfer Pricing Challenges in the Mining Sector, Natural Resources Governance Institute, available at <http://www.resourcegovernance.org/sites/default/files/documents/nrgi_transferpricing-study.pdf>

Shay, S. (2017), 'An Overview of Transfer Pricing in Extractive Industries', in P. Daniel, M. Keen, A. Swistak and V. Thuronyi (eds), International Taxation and the Extractive Industries, New York and London: Routledge

Sunley, E., Baunsgaard, T. and Simard, D. (2002) Revenue from the Oil and Gas Sector: Issues and Country Experience (IMF post-conference draft), available at $<$ http://siteresources.worldbank.org/INTTPA/Resources/SunleyPaper.pdf>

(2001) The Tax Treatment of the Mining Sector: An IMF Perspective, available at <http://siteresources.worldbank.org/INTOGMC/Resources/sunley-baunsgaard.pdf>

United States Congress (2010) Present Law and Background Related to Possible Income Shifting and Transfer Pricing, Joint Tax Committee JCX-37-10

United States General Accounting Office (1995) International Taxation - Transfer Pricing and Information on Nonpayment of Tax, GAO/GDD-95-101 


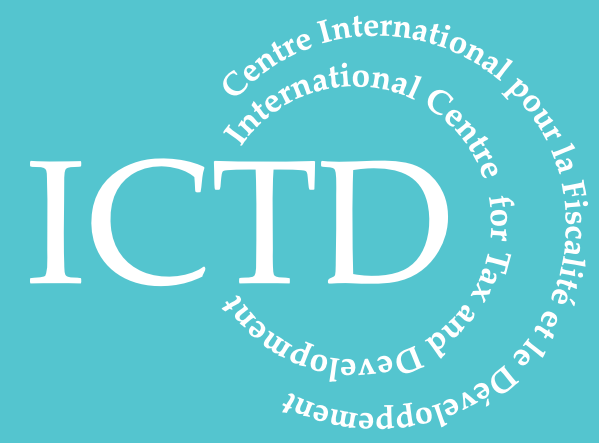

International Centre for Tax and Development at the Institute of Development Studies

Brighton BN1 9RE, UK

T: +44 (0) 1273606261

F: $+44(0) 1273621202$

E: info@ictd.ac

www.ictd.ac 